\title{
Proximate Composition of Local Salt Licks (Toka) in Adamawa State, Nigeria
}

\author{
Kubkomawa Hayatu Ibrahim \\ Department of Fisheries Technology, School of Agricultural Technology, the Federal Polytechnic, Mubi, Nigeria
}

Email address:

kubkomawa@yahoo.com

\section{To cite this article:}

Kubkomawa Hayatu Ibrahim. Proximate Composition of Local Salt Licks (Toka) in Adamawa State, Nigeria. Animal and Veterinary Sciences. Vol. 9, No. 1, 2021, pp. 1-4. doi: 10.11648/j.avs.20210901.11

Received: January 8, 2021; Accepted: January 18, 2021; Published: January 28, 2021

\begin{abstract}
The study investigated the proximate composition of local salt licks (toka) in Adamawa State, Nigeria with a view to reveal the feeding value of the products and use as a substitute to the expensive conventional ones. Six novel mineral blocks from different sources (maize stover, maize comb and sorghum stover ) produced from Mubi-North and Madagali Local Government Areas were used for analysis. The proximate compositions of the samples were analyzed at the Clinical Biochemical Laboratory of Adamawa State University (ADSU) Mubi, Nigeria. Parameters determined include crude protein (CP), crude fiber (CF), ether extract (EE), ash (AS) and moisture content (MC). Local salt licks (toka) had low mean crude protein $(\mathrm{CP})$ of $3.9 \%$, crude fibre $(\mathrm{CF})$ of $0.8 \%$, ether extract $(\mathrm{EE})$ of $1.1 \%$, ash of $0.8 \%$ and moisture content of $15.6 \%$. Irrespective of the low nutrient composition of novel mineral licks, they can be used to improve acceptability, palatability and mineral supplementation in livestock feeds. This showed that, with time and good awareness, livestock producers will opt for the products as source of mineral supplements since they are cheaper and readily available in the study area. This could also conveniently substitute the usually imported, highly expensive mineral licks used for livestock production in the state and Nigeria as a whole.
\end{abstract}

Keywords: Local Salt Licks, Livestock, Adamawa State, Nigeria

\section{Introduction}

Many plant and animal parts are being investigated and tested for new products such as low cost feeds which are nutritious, attractive and acceptable to livestock just like conventional feeds. Feed resources that contain mineral elements include; range or pasture plants, harvested forages, concentrates and mineral supplements [1]. Forage intake by pastoral grazing ruminants depends on the level of mineral consumption. Conventional mineral licks used in livestock production in tropical Africa and Nigeria in particular, are usually imported and highly expensive beyond the reach of a common farmer [2].

Local salt licks, also known as toka in Hausa, are locally produced from ashes of crop residues and animal dung indigenous to North-Eastern Nigeria. Mineral licks generally provide bio-metals such as sodium, calcium, potassium, magnesium, phosphorus, iron, zinc and other trace elements required for the development of bones, muscles, growth and functioning of other systems in livestock and wildlife [3, 4,
10-13]. Research has shown other uses and nutritional benefits of mineral licks to include selenium (Se), cobalt (Co) and molybdenum (Mo) [4].

Conventional salt licks used by farmers for years in many developing and developed countries especially, mixtures of liquid molasses and urea, which provides fermentable nitrogen and are good sources of minerals are highly expensive and beyond the reach of a common farmer. However, proximate composition of local salt licks (toka) is not known. There is no up to date literature on the proximate composition of this local salt licks (toka) in Adamawa State, Nigeria. This study, therefore, generated the information that could be used by small scale farmers to optimize feeding mineral licks during different seasons of the year, especially during the lean feed resource periods. It could, also, contribute to the actual decision frame-works of immediate local authorities on the development of these local salt licks (toka) resources. The present study, also, provided baselines for future in-depth investigation into acceptable and adoptable use of local salt licks (toka) in Adamawa State, 
Nigeria. The objective of the study was to investigate proximate composition of local salt licks (toka) in Adamawa State, Nigeria with a view to reveal the feeding value of the products and use as a substitute to the expensive conventional ones.

\section{Materials and Methods}

\subsection{The Study Area}

Adamawa State is located at the area where the River Benue enters Nigeria from Cameroon Republic and is one of the six states in the North-East geopolitical zone of Nigeria. It lies between latitudes 70 and 110 North of the Equator and between longitudes 110 and 140 East of the Greenwich Meridian [6]. It shares an international boundary with the Republic of Cameroon to the East and interstate boundaries with Borno to the North, Gombe to the North-West and Taraba to the South-West [7], as shown in Figure 1.

Cash crops grown in the state include cotton and groundnuts, sugarcane, cowpea, benniseed, bambara nuts and tiger nuts, while food crops include maize, yam, cassava, sweet potatoes, guinea corn, millet and rice. The communities living on the banks of rivers engage in fishing, while the other tribes, especially the Fulanis are pastoralists who rear livestock such as cattle, sheep, goats, donkeys, few camels, horses and poultry for subsistence [7-9].

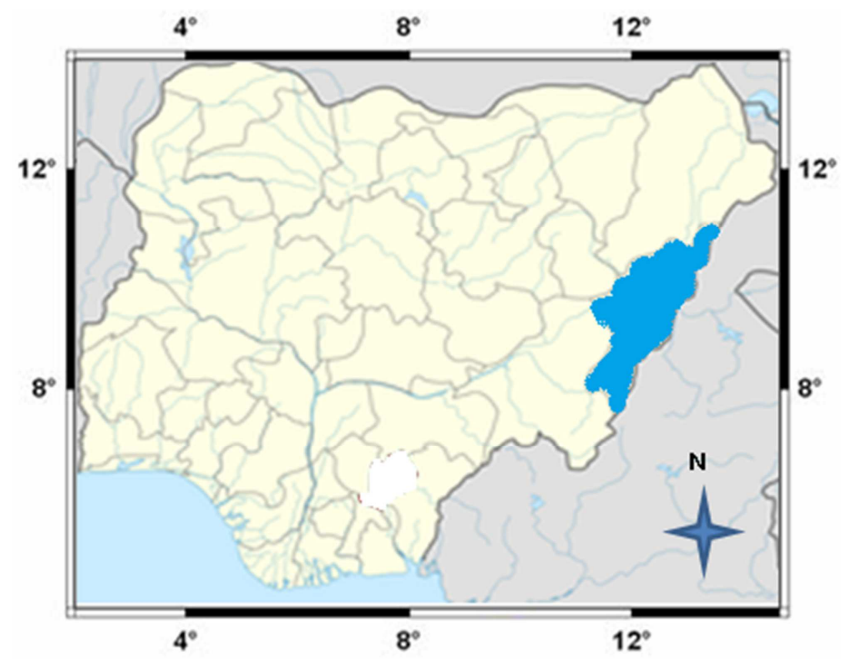

Figure 1. Map of Nigeria Showing Adamawa State as a Study Area.

\subsection{Production Techniques}

Dry crop residues are carefully selected from the field at about $10-23 \%$ moisture content and packed to a floor or open field, usually at the farm. The materials are then burnt to ashes under cool wind-free atmosphere and allowed to cool to a room or environmental temperature as described [5]. The ashes are carefully and gently gathered using a broom and packed into pots/containers. Fine grasses are obtained to serve as sieve which is put into clean iron or clay pots/ containers with holes or perforated bottoms. The ashes are packed into the perforated pots/ containers filled to the brim and mounted on another clean pots/containers without perforation but of the same sizes with the perforated ones or supported with stones if the perforated are bigger than the intact containers. Water is sprinkled on the ashes gently and gradually until it is fully soaked and submerged. More water is added gradually and continually until the containers are filled. The system is allowed to stay overnight and the concentrated mineral solution filtered or leached down slowly into the clean pots/containers serving as collection chambers. The concentrated mineral solution is then boiled while constantly adding ashes and stirring with a long cooking spoon for six to eight hours. The solution then forms paste like product, as the water evaporates leaving only the solid mineral licks. The product is then molded into blocks using small plastic containers polished with groundnut oil to prevent the mineral blocks sticking in them and to ease removal of blocks after sun-drying for 2 days. The process takes 2 to 3 days to complete the production cycle as shown in in Figures 1, 2 and 3.

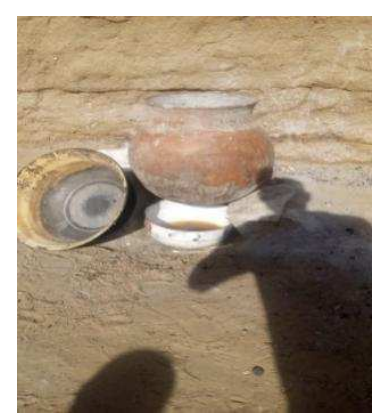

Figure 2. Filtering of Mineral Solution into the Collection Chamber After soaking with water.

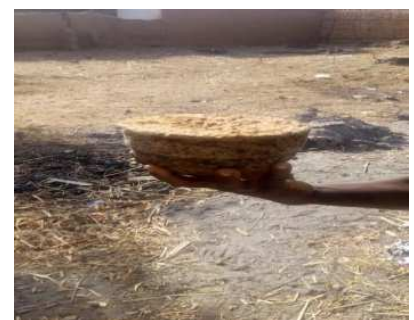

Figure 3. Molded and Sun-Dried Local Salt Block.

\subsection{Proximate Analysis of Samples}

Six novel mineral blocks from different sources (maize stover, maize comb and sorghum stover ) produced from Mubi-North and Madagali Local Government Areas were used for analysis.

The proximate compositions of the samples were analyzed at the Clinical Biochemical Laboratory of Adamawa State University (ADSU) Mubi, Nigeria. Parameters determined include crude protein $(\mathrm{CP})$, crude fiber $(\mathrm{CF})$, ether extract (EE), ash (AS) and moisture content (MC) as described by AOAC [10].

\subsection{Data Analysis}

Data generated were subjected to descriptive statistics such 
frequencies, percentages, means and tables to explain the proximate composition of novel mineral licks (toka) in Adamawa State, Nigeria.

\section{Results and Discussion}

\subsection{Proximate Composition of Local Salt Licks (Toka) in Adamawa State, Nigeria}

Livestock production in Nigeria and elsewhere in the tropics depends largely on feed availability and supply. This also depends on the producer's intellectual capability to offer the required nutrients according to the classes of animals to be fed. Feeding livestock with wrong nutrients is like wasting time and resources. Animals are kept for specific production purposes and have to be fed according to the specifications for optimal productivity. For optimal production and quality product presentation, livestock feeds have to be analyzed.

\subsection{Crude Protein (CP)}

Table 1. Proximate Composition of Novel Mineral Licks in Adamawa State.

\begin{tabular}{|c|c|c|c|c|}
\hline Parameters & & $\begin{array}{l}\text { Mubi North } \\
(\%)\end{array}$ & $\begin{array}{l}\text { Madagali } \\
(\%)\end{array}$ & $\begin{array}{l}\text { Mean } \\
(\%)\end{array}$ \\
\hline \multicolumn{5}{|c|}{ Crude Protein } \\
\hline & Maize Stover & 3.1 & 3.2 & 3.2 \\
\hline & Maize Comb & 4.9 & 4.4 & 4.7 \\
\hline & Sorghum Stover & 3.7 & 3.7 & 3.7 \\
\hline & Overall Mean & & & 3.9 \\
\hline \multicolumn{5}{|l|}{ Crude Fiber } \\
\hline & Maize Stover & 0.8 & 0.9 & 0.9 \\
\hline & Maize Comb & 0.4 & 0.6 & 0.5 \\
\hline & Sorghum Stover & 0.9 & 1.1 & 1.0 \\
\hline & Overall Mean & & & 0.8 \\
\hline \multicolumn{5}{|l|}{ Ether Extract } \\
\hline & Maize Stover & 0.9 & 1.2 & 1.1 \\
\hline & Maize Comb & 1.2 & 1.4 & 1.3 \\
\hline & Sorghum Stover & 0.7 & 1.0 & 0.9 \\
\hline & Overall Mean & & & 1.1 \\
\hline \multicolumn{5}{|l|}{ Ash } \\
\hline & Maize Stover & 0.6 & 0.6 & 0.6 \\
\hline & Maize Comb & 0.6 & 0.8 & 0.7 \\
\hline & Sorghum Stover & 1.1 & 1.0 & 1.1 \\
\hline & Overall Mean & & & 0.8 \\
\hline \multicolumn{5}{|c|}{ Moisture Content } \\
\hline & Maize Stover & 19.8 & 11.8 & 15.8 \\
\hline & Maize Comb & 10.6 & 17.7 & 14.2 \\
\hline & Sorghum Stover & 15.1 & 18.2 & 16.7 \\
\hline & Overall Mean & & & 15.6 \\
\hline
\end{tabular}

The overall mean crude protein (CP) value of novel mineral licks at the two locations was low $(3.9 \%)$, with the range of $3.2-4.7 \%$ as shown in table 1 . The highest $\mathrm{CP}$ of $4.7 \%$ obtained in maize comb is however too low to support rumen microbial activities and energy supply, therefore, too poor to be used alone in animal feeding as source of protein. These findings disagreed with [15] who reported urea mineral block to be an excellent supplementary feed that could be formulated and used to increase digestion of roughages, provide protein and energy to ruminant animals. Similarly, [14, 16] also reported that, urea mineral block provides crude protein $(\mathrm{N})$ that is usually deficient in dry feeds. This crude protein $(\mathrm{N})$ provides enough microbial protein needed for the maintenance and growth of animals. The findings of this study are in order since novel mineral licks are not used in animal feeding to supply protein but as mineral supplements in addition to what obtained from forages. Therefore, despite the low $\mathrm{CP}$ content of the products, their nutritional contributions in livestock feeding is paramount.

\subsection{Crude Fiber (CF)}

The overall mean crude fibre (CF) content of novel mineral licks was $0.8 \%$, with sorghum stover recording the highest value of $1.0 \%$, while the range was between 0.5 to $1.0 \%$. High $\mathrm{CF}$ in livestock feed may be detrimental to digestion since it represents insoluble carbohydrate e.g. alkali insoluble lignin, as well as fibre bound nitrogen and cellulose. The low CF obtained in this study shows that, novel mineral licks can easily be digested and assimilated by the animals as source of mineral supplements.

\subsection{Fat (EE)}

The overall mean ether extract (EE) value stood at 1.1\% with a range of $0.9-1.3 \%$, indicating very low fat content of these products. The results are not out of place since the novel mineral licks are produced from maize and sorghum residues which are basically carbohydrate feeds and not proteins. It also indicates that, novel mineral licks are not multi-nutrients and cannot be fed as sole feed.

\subsection{Ash}

The overall mean ash value of $0.8 \%$ was also low, with values ranging from 0.6 to $1.1 \%$ as can be seen in table 1 . The ash proximate composition should represent the mineral content of the feed which could be of value in other agricultural applications such as straw treatment to improve their nutrient, palatability and acceptability. Though, novel mineral licks are processed and refined products obtained from ashes of crop residues and so, the ash content should not be high.

\subsection{Moisture}

The overall mean moisture content of novel mineral licks was $15.6 \%$ with values ranging from 14.2 to $16.7 \%$ as can be seen in table 1 . The results showed that, the products are not liquid but solid feeds which could be diluted in high volume of water for the treatment of straws for feeding livestock.

\section{Conclusion and Applications}

The proximate composition of local salt licks (toka) revealed low $\mathrm{CP}, \mathrm{CF}, \mathrm{EE}$, ash and moisture content which means that, the products are truly mineral supplements. The analysis showed that, the products are within their normal compositional parameters and not adulterated.

It is concluded that, novel mineral licks if properly handled would serve as good source of mineral supplements for 
livestock in the study area. There is, therefore, a greater prospect for novel mineral licks production in the study area as sooner or later the livestock industry will fully key into utilization of the products for livestock production as a cheaper and readily available source of mineral supplements. Thus, novel mineral licks indigenous to people of the study area locally produced from ashes of crop residues would conveniently substitute those expensive conventional imported sources and save the livestock farmers a great component of their production costs.

Institutions such as Polytechnics, Colleges of Education, Colleges of Agriculture and the Universities which run animal production courses, local and commercial livestock producers should be encouraged to patronize novel mineral licks as cheaper and readily available mineral licks for animals. There is a need for further research to reveal more feeding potentials of novel mineral licks in Adamawa State and Nigeria as a whole.

\section{References}

[1] Babayemi, O. J., Abu, O. A., \& Opakunbi, A. (2014). Integrated animal husbandry for schools and colleges, First edition. Positive Press Ibadan, Nigeria, pp. 20-122.

[2] Kubkomawa, H. I. (2017a). Supplementary Conventional Mineral Licks and the Productivity of Ruminant Animals in Tropical Africa: A Review. International Journal of Research Studies in Agricultural Sciences (IJRSAS), 3 (9): 45-57.

[3] Black, J. G., Mosquera, D., Guerra, J., Loiselle, B. A., Romo, D., \& Swing, K. (2011). "Mineral licks as diversity hotspots in lowland forest of Eastern Ecuador". Diversity, 3 (2), 217-234.

[4] Mills, A., \& Milewski, A. (2007). "Geophagy and nutrient supplementation in the Ngorongoro conservation area, Tanzania, with particular reference to selenium, cobalt and molybdenum". Journal of Zoology, 271 (1), 110-118.

[5] Kubkomawa, H. I. (2017b). Development of Novel Mineral Licks (Toka) and the Livestock Industry Boom in Northeastern Nigeria. International Journal of Animal Research (IJAR), 1 (2): 0001-0020.
[6] Mohammed, K. (1999). Historical background. In A. A. Adebayo and A. L. Tukur (Ed) Adamawa State in Maps. Yola, Paraclete Publishers, Pp. 39-84.

[7] ASMLS (2010). Map of Nigeria Showing all States. Adamawa State Ministry of Land and Survey, Yola, Nigeria.

[8] Adebayo, A. A. and Tukur, A. L. (1997). Adamawa State in Maps, Yola, Paraclete Publishers, pp. 8-45.

[9] Adebayo, A. A. (1999). Climate, Sunshine, Temperature, Relative Humidity and Rainfall. Journal of Applied Sciences and Management, 1, 69-72.

[10] AOAC (2004). Association of official analytical chemists. Official methods of analysis (21st Edition) Washington DC USA.

[11] Puto (2015). Rice Recipes. Philippine Rice Research Institute.

[12] NRC (1980). Mineral tolerance of domestic animals. National Research Council, Washington, D.C., National Academy of Sciences.

[13] Upadhyay, N., Tiwari, M. R., Pandey, L. N., Karki, T. B., Acharya, R. Gairhe, S., \& Acharya, Y. (2018). Economic analysis of the urea molasses mineral block feeding to lactating cattle of Nepal. Nepalese Journal of Agricultural Sciences, (16), 49-57.

[14] FAO (2007). Food and Agricultural Organization. Experiences with urea-molasses multinutrient blocks in buffalo production and reproduction in smallholder dairy farming, Punjab, India. Food and Agriculture Organization of the United Nations Rome. pp. 59-70.

[15] Geleta, T. (2013). Effect of supplementing grazing Arsi-Bale sheep with molasses-urea feed block on weight gain and economic return under farmers' management condition. Journal of Cell and Animal Biology, 7 (10), 125-131.

[16] Adugna, T., M. C. Roger, G. L. Arthur, S. Tilahun and N. Tegene (2000). Nutritional constraints and future prospective for Goat Production in East Africa. In: proceeding of the conference on opportunities and challenges of enhancing goat production in east Africa, November 2000, Langston University, Langston, USA and Debub University, Awassa, Ethiopia. pp. 1-21. 